\title{
The Readmission of Preterm Infants of 30-33 Weeks Gestational Age within 1 Year Following Discharge from Neonatal Intensive Care Unit in Korea
}

Jang Hoon Lee, M.D., Myo Jing Kim, M.D.*, Young Don Kim, M.D. , Soon Min Lee, M.D. , Eun Song Song, M.D. , So Yoon Ahn, M.D. ", Chun Soo Kim, M.D. ", Jae Woo Lim, M.D.**, Meayoung Chang, M.D. ${ }^{\dagger+}$, Hyun-Seung Jin, M.D. ${ }^{\ddagger}$, Jong Hee Hwang, M.D. ${ }^{\S}$, Woo Ryoung Lee, M.D." " , and Yun Sil Chang, M.D. "; For the Committee on Data Collection and Statistical Analysis of the Korean Society of Neonatology

Department of Pediatrics, Ajou University Hospital, Suwon, Department of Pediatrics*, Dong-A University Hospital, Busan, Department of Pediatrics ${ }^{\dagger}$, Jeju National University Hospital, Jeju, Department of Pediatrics ${ }^{\ddagger}$, Yonsei University Gangnam Severance Hospital, Seoul, Department of Pediatrics ${ }^{\S}$ Chonnam National University Hospital, Gwangju, Department of Pediatrics", Samsung Medical Center, Sungkyunkwan University School of Medicine, Department of Pediatrics ${ }^{\top}$, Keimyung University Dongsan Medical Center, Daegu, Department of Pediatrics**, Konyang University Hospital, Daejeon, Department of Pediatrics ${ }^{\dagger \dagger}$, Chungnam National University Hospital, Daejeon, Department of Pediatrics ${ }^{\ddagger}$, Gangneung Asan Hospital, Gangneung, Department of Pediatrics ${ }^{\S \S}$, Inje University Ilsan Paik Hospital, Goyang, Department of Pediatrics" ", Soonchunhyang University Hospital, Seoul, Korea

\section{ABSTRACT}

Purpose: This study was conducted to evaluate the readmission rate of preterm infants of 30-33 weeks gestational age (GA) within 1 year following discharge from the neonatal intensive care unit (NICU).

Methods: This research was a part of the Retrospective Study to Evaluate Rehospitalization \& Health Care Utilization after NICU Discharge in Preterm Infants ( $\leq 33$ weeks) II (RHANPI II) project conducted by the Committee on Data Collection and Statistical Analysis of the Korean Society of Neonatology. Enrolled infants $(n=1,257)$ of 46 hospitals from April to September 2012, were retrospectively studied.

Results: The average GA and birth weight of the study population was $32^{+2} \pm 1^{+1}$ weeks and $1,785 \pm 386 \mathrm{~g}$, respectively. The cumulative readmission rate during the 360 days following discharge from the NICU was $27.3 \%$. The cumulative readmission rate according to GA was $36.4 \%, 30.1 \%, 25.9 \%$ and $22.7 \%$ for infants born at $30,31,32$ and 33 weeks GA, respectively. The corresponding respiratory readmission rate was $16.3 \%$; this was $59.8 \%$ of total readmissions. There was no significant difference in the respiratory readmission rate according to GA group (log-rank test for trend, $P$-value= 0.0558). Of the infants who were readmitted with respiratory problems, $57.0 \%$ ( $\mathrm{n}=$ 53/93) tested positive for respiratory syncytial virus (RSV).

Conclusion: The cumulative readmission rate during the 360 days following discharge from the NICU was $27.3 \%$. Respiratory problems were the most common cause of readmission, and RSV was the most common virus associated with respiratory readmission. Additionally, there was no difference in the rate of respiratory readmission according to GA group.

Key Words: Infants, Premature, Readmission, Respiratory syncytial virus
Received: 6 September 2014

Revised: 13 September 2014

Accepted: 15 September 2014

Correspondence to:

Yun Sil Chang, M.D.

Department of Pediatrics,

Samsung Medical Center,

Sungkyunkwan University School

of Medicine, 50 Irwon-dong,

Gangnam-gu, Seoul 135-710,

Korea

Tel: $+82-2-3410-3528$

Fax: +82-2-3410-0043

E-mail: yschang@skku.edu

\section{Copyright(c)}

By Korean Society of Neonatology.

All right reserved.

This is an Open-Access article distributed under the terms of the Creative Commons Attribution Non-Commercial License (http://creativecommons.org/licenses/ by-nc/3.0), which permits unrestricted non-commercial use, distribution, and reproduction in any medium, provided the original work is properly cited. 
서론

우리나라의 2013년 조출생률은 인구 1000명 당 8.6명 (통계청 발표)으로 사상 최저를 기록하였으며 2012년 합계출산율은 1.3 명으로 OECD 28개국 중 27위를 차지할 만큼 저출산이 사회적으 로 심각한 문제가 되고 있는 상황이다. 이에 따라 미숙아들의 생 존, 건강 및 의료 이용 행태에 대한 사회적 관심이 높아지고 있다. 이중에서도 미숙아의 재입원과 호흡기 질환은 신생아집중치료실 (neonatal intensive care unit, NICU) 퇴원 후 합병증의 이환율을 평가할 수 있는 지표로 사용되어 왔다 ${ }^{1}$. 미숙아들은 만삭아에 비 해 호흡기 감염이나 NICU 퇴원 후 재입원율이 높은데, 국외연구 에 따르면 $1,500 \mathrm{~g}$ 미만의 극소저체중출생아의 $38 \%{ }^{2}$ 가 생후 1 년 이내에 재입원하고 출생체중 $1,000 \mathrm{~g}$ 미만의 초극소저체중출생 아의 $49 \%{ }^{3)}$, 재태주령 29 주 미만 미숙아의 $47.3 \%{ }^{4)}$ 가 출생 후 1 년 안에 재입원한다는 보고가 있으며 이들의 재입원의 가장 큰 원인 은 호흡기계 질환이었다 ${ }^{5,6)}$.

한편 호흡기계 질환의 원인으로서 respiratory syncytial virus (RSV)는 영유아기 하기도 감염의 가장 중요한 원인으로 매년 계 절적 역학 발생을 보인닥) 미숙아로 출생하였거나 기관지폐이 형성증(bronchopulmonary dysplasia, BPD) 등의 만성폐질환 이 있는 영아는 RSV 관련 중증 하기도 질환이 특히 많이 발생하 여 미숙아의 RSV 관련 재입원은 2.7-45\%까지 보고되었으며 이 로 인한 사망률 역시 만삭아 군보다 더 높은 것으로 알려져 있 다 ${ }^{8-14)}$. 이러한 RSV 감염에 의한 재입원율을 감소시키기 위해 RSV 유행시기에 RSV 단클론 항체(monoclonal antibody)인 시 나지스(Synagis ${ }^{\circledR}$, palivizumab, MedImmune, Inc., Gaithersburg, Maryland, U.S.A.)투여 예방법이 널리 사용되고 있으며 ${ }^{15,16)}$, 국내 에서도 BPD가 있는 미숙아들에서 RSV 감염에 대해 시나지스 예 방요법(prophylaxis)이 시작되었고 2012 년부터는 재태주령 31 주 이하의 미숙아에서도 보험 적용이 확대 된 바 있다. 하지만 국 외에서는 재태주령 35 주 이하의 미숙아로 태어난 6 개월 미만의 영아에 대해서도 시나지스의 유효성과 안전성을 입증하고 이의
예방법에 대한 선택적 필요성을 제기하고 있다 ${ }^{10,17-19)}$.

이와 같이 미숙아에서 중요한 호흡기 감염 원인을 비롯한 $\mathrm{NICU}$ 퇴원 후 재입원에 대한 기존의 연구들은 주로 $\mathrm{BPD}$ 에 이환된 미숙 아 또는 극소저체중출생아 등 유병율이 높은 군에 해당하는 미숙 아를 대상으로 시행되었다. 최근 국외에서는 재태주령 28-31주 에 출생한 극소미숙아(very preterm infants)와 32-33주에 출생 한 중도미숙아(moderate preterm infants) 등 재태주령은 더 높 고 인구학적으로 그 수가 더 많으나 여전히 취약하기에 의료 사회 적으로 또 다른 중요성을 갖는 중등도 미숙아들의 재입원율 등의 의료 서비스 이용에 대한 연구 결과가 활발히 보고되고 있다 ${ }^{20-23)}$. 그러나 국내에서는 이들을 중심으로 한 연구가 거의 전무한 실정 이다.

이에 본 연구자들은 국내 다기관 후향적 연구를 통하여 중도미 숙아와 이에 가까운 극소미숙아인 재태주령 30-33주 미숙아들이 $\mathrm{NICU}$ 퇴원 후 1 년간 얼마나 재입원하며 그 원인으로 호흡기 관련 이 어느 정도이고 또한 이중 RSV 감염 관련율은 얼마인지를 알아 보고자 하였다.

\section{대상 및 방법}

본 연구는 대한신생아학회 조사통계위원회에서 주관한 " $\mathrm{Re}-$ trospective Study to Evaluate Rehospitalization \& Health Care Utilization After NICU Discharge in Preterm Infants ( $\leq 33$ weeks) II (RHANPI II)" 연구 프로젝트 중 하나로 진행되었다. 2012년 4 월 1일부터 2012년 9월 30일까지 만 6개월 동안 출생하여 전국 의 46개 병원 NICU에 입원한 재태주령 30-33주에 출생한 미숙아 $(n=1,289)$ 중 NICU에서 사망한 32명 $(30$ 주: $n=10,31$ 주: $n=7,32$ 주: $n=7,33$ 주: $n=8)$ 을 제외한 1,257 명의 의무기록 조사를 통한 관찰 연구로 진행되었다. 2013년 10월 31일까지의 의무기록을 토 대로 가장 최근에 시행된 진료 날짜를 확인하여 계산된 NICU 퇴 원 후 추적 관찰 기간의 평균은 $296 \pm 169$ 일로 대상자들의 추적일 수 분포는 Figure 1 과 같았다.

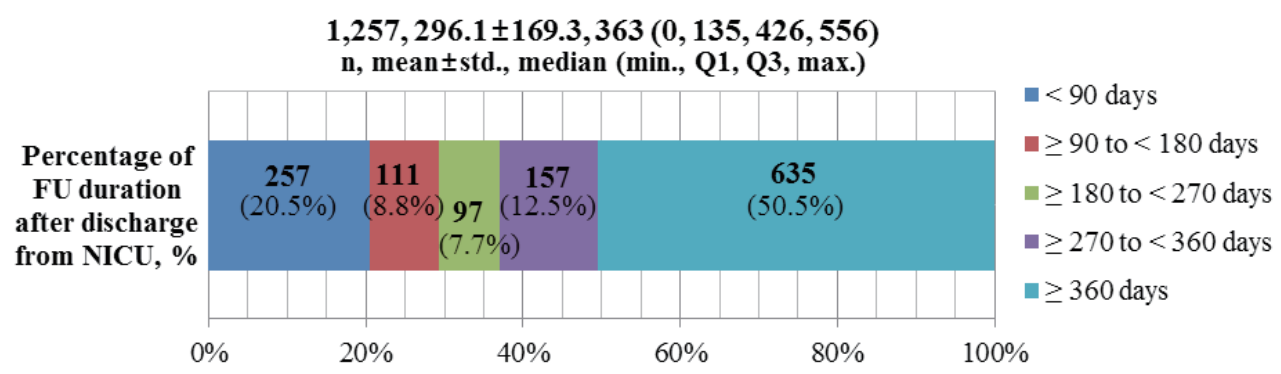

Figure 1. Follow-up duration of preterm infants following discharge from the neonatal intensive care unit (NICU). The mean value and standard deviation of the duration was $296 \pm 169$ days. 
각 병원의 신생아세부전문의가 표준화된 변수 정의 매뉴얼에 의거 등록 환아의 의무기록을 후향적으로 조사하여 웹 기반 전 자증례기록시스템에 입력하였다. 수집된 정보의 정확성을 확보 하기 위해 누락 및 오류로 생각되는 변수 항목에 대해 정보 확인 (data validation)과 정보 감사(data verification)를 통해 쿼리를 발 생하여 개별 병원의 세부전문의에게 확인 및 수정을 요청하고 해 결하였다.

전자증례기록서는 대한신생아학회 조사통계위원회와 삼성서 울병원(임상의학연구소) A-CRO팀이 공동 개발하였으며, 데이터 베이스는 Oracle사의 RDC (Remote Data Capture)시스템을 기반 으로 하였다. 이 연구는 46 개 참여병원 각각의 개별 기관윤리심의 를 거쳐 동의 면제를 받아 진행하였다. 수집 정보는 신생아집중치 료와 관련된 인구학적 정보 및 신생아기 주요합병증과 NICU 퇴원 후 입원 여부, 입원 시기 및 사유, 호흡기 관련 재입원의 경우 호흡 기 바이러스 검사 여부와 종류 등으로 이루어졌다.

$\mathrm{BPD}$ 는 교정 재태주령 36 주의 산소 의존도에 따라 정의하였 다 ${ }^{24)}$. 신생아괴사장염(necrotizing enterocolitis, NEC)은 Bell 의 분류 병기 II 이상으로 정의하였다 ${ }^{25)}$. 병기 III-IV 뇌실내 출혈 (intraventricular hemorrhage, IVH)과 낭성뇌실주위백질연화 증(cystic periventricular leukomalacia, PVL)은 뇌초음파 결과를
Papil의 병기분류체계에 따라 정의하였다 ${ }^{26)}$. 패혈증은 Centers for Disease Control and Prevention/National Nosocomial Infection Surveilance (NNIS) 의 12 개월 미만 영아의 패혈증에 대한 정의를 사용하였다 ${ }^{27)}$.

연속형 변수에 대해서는 평균과 표준편차를 제시하고, 범주형 변수에 대해서는 기술통계량으로 빈도수와 백분율(\%)을 제시하 였으며, 백분율은 소수점 둘째 자리에서 반올림하여 소수점 첫째 자리까지 나타내었다. 각 미숙아에서 첫번째 재입원(또는 호흡기 재입원)이 발생하기까지의 시간을 산출하여 시간에 따른 누적 발 생률을 Kaplan-Meier product limit 방법을 이용하여 산출하였으 며, Log-rank 검정을 통하여 재입원율 및 호흡기 재입원율의 재 태주령 별 차이를 추정하였다. 모든 통계분석은 통계 소프트웨어 SAS version 9.4 (SAS Institute, Cary, NC, USA)와 Stata SE version 13 (Stata Corporation, College Station, TX, USA)를 사용하였고, 통계적 유의성 검정은 유의수준 5\% 하에서 양측검정 (two-sided test)을 수행하였다. $P$ 값이 5\% 미만인 경우 통계학적으로 유의한 것으로 판단하였다. 제 1종 오류 보정이 필요한 경우 Bonferroni's correction 방법을 적용하였다.

Table 1. Baseline Demographics of the Enrolled Infants

\begin{tabular}{|c|c|c|c|c|c|}
\hline & & Followec & -up infant post $N$ & U discharge & \\
\hline & $\begin{array}{l}\text { Total infants } \\
(n=1,257)\end{array}$ & $\begin{array}{c}30 \text { weeks } \\
\text { gestational age } \\
(n=177)\end{array}$ & $\begin{array}{c}31 \text { weeks } \\
\text { gestational age } \\
(n=259)\end{array}$ & $\begin{array}{c}32 \text { weeks } \\
\text { gestational age } \\
(n=335)\end{array}$ & $\begin{array}{c}33 \text { weeks } \\
\text { gestational age } \\
(n=486)\end{array}$ \\
\hline Gestational age, week & $32^{+2} \pm 1^{+1}$ & $30^{+3} \pm 0^{+2}$ & $31^{+3} \pm 0^{+1}$ & $32^{+3} \pm 0^{+2}$ & $33^{+3} \pm 0^{+2}$ \\
\hline Birth weight, $g$ & $1,785 \pm 386$ & $1,445 \pm 301$ & $1,608 \pm 302$ & $1,784 \pm 298$ & $2,004 \pm 367$ \\
\hline$<750$ & $5(0.4)$ & $4(2.3)$ & $1(0.4)$ & - & - \\
\hline $750-1,000$ & $25(2.0)$ & $9(5.1)$ & $9(3.5)$ & $6(1.8)$ & $1(0.2)$ \\
\hline $1,000-1,250$ & $80(6.4)$ & $22(12.4)$ & $26(10.0)$ & $14(4.2)$ & $18(3.7)$ \\
\hline $1,250-1,500$ & $169(13.4)$ & $65(36.7)$ & $44(17.0)$ & $32(9.6)$ & $28(5.8)$ \\
\hline$\geq 1,500$ & $978(77.8)$ & $77(43.5)$ & $179(69.1)$ & $283(84.5)$ & $439(90.3)$ \\
\hline Male & $687(54.7)$ & $91(51.4)$ & $146(56.4)$ & $190(56.7)$ & $260(53.5)$ \\
\hline In-born & $1191(94.8)$ & $163(92.1)$ & 247 (95.4) & $317(94.6)$ & $464(95.5)$ \\
\hline Multiple pregnancy & $390(31.0)$ & $46(26.0)$ & $67(25.9)$ & $109(32.5)$ & $168(34.6)$ \\
\hline Antenatal corticosteroid ${ }^{*}$ & $750(61.9)$ & $115(69.3)$ & $158(63.7)$ & $219(67.4)$ & $258(54.5)$ \\
\hline Small for gestational age ${ }^{\dagger}$ & $132(10.5)$ & $17(9.7)$ & $40(15.4)$ & $34(10.1)$ & $41(8.4)$ \\
\hline Caesarean section $^{\dagger}$ & $857(68.3)$ & $113(63.8)$ & $178(69.0)$ & $241(71.9)$ & $325(67.0)$ \\
\hline Maternal age, year ${ }^{\neq}$ & $32.0 \pm 4.4$ & $32.7 \pm 4.6$ & $32.2 \pm 4.2$ & $32.1 \pm 4.4$ & $31.6 \pm 4.4$ \\
\hline Elder siblings ${ }^{\S}$ & $533(43.8)$ & $75(44.4)$ & $121(47.8)$ & $127(39.0)$ & $210(44.8)$ \\
\hline
\end{tabular}

Values are the numbers (\%) or mean \pm standard deviation.

*The 45 cases with unknown value were excluded.

${ }^{\dagger}$ The 2 cases with unknown value were excluded.

${ }^{\ddagger}$ The 1 case with unknown value was excluded.

${ }^{\text {s}}$ The 40 cases with unknown value were excluded. 


\section{결과}

\section{1. 인구학적 특성}

본 연구의 분석 대상인 1,257 명의 전체 및 재태주령 별 인구학 적 특징은 Table 1 과 같았다. 이들 전체의 평균 재태주령은 $32^{+2}$ $\pm 1^{+1}$ 주, 출생체중은 $1,785 \pm 386 \mathrm{~g}$ 이었다. 재태주령 별 분포는 각 각 30주는 177명 (14.1\%), 31주는 259명 (20.6\%), 32주는 335명 (26.7\%), 33주는 486명(38.6\%) 이었다. 대상 환아 중 NICU 퇴원
후 사망한 환아는 총 2 명으로 재태주령 32 주에 출생하였던 환아 들이었다.

\section{2. 신생아기 주요합병증}

전체 및 재태주령 별 환아들의 NICU 퇴원 시의 주요 합병증 의 유병율은 Table 2와 같았다. 이들의 NICU 퇴원 시 생존율은 $97.5 \%(1,257 / 1,289)$ 였으며 BPD의 유병율은 7.4\% (93/1,257) 이었다.

Table 2. Outcomes of the Enrolled Infants in the Neonatal Intensive Care Unit

\begin{tabular}{|c|c|c|c|c|c|}
\hline & \multicolumn{5}{|c|}{ Followed-up infant post NICU discharge } \\
\hline & $\begin{array}{c}\text { Total infants } \\
(n=1,257)\end{array}$ & $\begin{array}{c}30 \text { weeks } \\
\text { gestational age } \\
(n=177)\end{array}$ & $\begin{array}{c}31 \text { weeks } \\
\text { gestational age } \\
(n=259)\end{array}$ & $\begin{array}{c}32 \text { weeks } \\
\text { gestational age } \\
(n=335)\end{array}$ & $\begin{array}{c}33 \text { weeks } \\
\text { gestational age } \\
(n=486)\end{array}$ \\
\hline Use of surfactant* & $449(35.9)$ & $107(60.8)$ & $126(49.0)$ & $105(31.5)$ & $111(22.8)$ \\
\hline Patent ductus arteriosus ${ }^{\dagger}$ & $207(17.1)$ & $53(30.5)$ & $68(26.5)$ & $42(13.1)$ & $44(9.6)$ \\
\hline \multicolumn{6}{|l|}{ Bronchopulmonary dysplasia $^{\ddagger}$} \\
\hline Mild & $93(7.4)$ & $43(24.6)$ & $29(11.2)$ & $10(3.0)$ & $11(2.3)$ \\
\hline Moderate & $56(4.5)$ & $23(13.1)$ & $18(7.0)$ & $8(2.4)$ & $7(1.4)$ \\
\hline Severe & $26(2.1)$ & $15(8.6)$ & $7(2.7)$ & $1(0.3)$ & $3(0.6)$ \\
\hline Retinopathy of prematurity ( $\geq$ stage 2$)^{\S}$ & $11(0.9)$ & $5(2.9)$ & $4(1.5)$ & $1(0.3)$ & $1(0.2)$ \\
\hline Necrotizing enterocolitis ( $\geq$ stage 2$)^{\|}$ & $27(2.2)$ & $8(4.6)$ & $4(1.5)$ & $8(2.5)$ & $7(1.5)$ \\
\hline Intraventricular hemorrhage ( $\geq$ grade 3 ) & $9(0.7)$ & $3(1.7)$ & $1(0.4)$ & $4(1.2)$ & $1(0.2)$ \\
\hline Cystic periventricular & $7(0.6)$ & $2(1.1)$ & $1(0.4)$ & $3(0.9)$ & $1(0.2)$ \\
\hline leukomalacia ${ }^{\uparrow}$ & $32(2.6)$ & $16(9.1)$ & $9(3.5)$ & $3(0.9)$ & $4(0.8)$ \\
\hline Sepsis ** & $75(6.0)$ & $19(10.9)$ & $26(10.0)$ & $16(4.8)$ & $14(2.9)$ \\
\hline
\end{tabular}

Values are the numbers (\%).

*The 5 cases with unknown value were excluded.

${ }^{\dagger}$ The 47 cases with unknown value were excluded.

${ }^{*}$ The 7 cases with unknown value were excluded.

${ }^{\S}$ The 50 cases with unknown value were excluded.

"The 5 cases with unknown value were excluded.

"The 17 cases with unknown value were excluded.

** The 2 cases with unknown value were excluded.

Table 3. Readmission Rate of the Enrolled Infants Following Discharge from the Neonatal Intensive Care Unit

\begin{tabular}{|c|c|c|c|c|c|c|}
\hline \multirow{2}{*}{$\begin{array}{l}\text { Gestational age, } \\
\text { week }\end{array}$} & \multirow[b]{2}{*}{ No. of total } & \multirow{2}{*}{$\begin{array}{l}\text { No. of 1st } \\
\text { readmission } \\
(\%)\end{array}$} & \multirow{2}{*}{$\begin{array}{c}\text { No. of } \\
\text { censored }^{\dagger} \\
(\%)\end{array}$} & \multicolumn{3}{|c|}{ Readmission rate* } \\
\hline & & & & $\begin{array}{c}\text { at } 90 \text { days } \\
(95 \% \mathrm{CI})\end{array}$ & $\begin{array}{l}\text { at } 180 \text { days } \\
(95 \% \mathrm{CI})\end{array}$ & $\begin{array}{l}\text { at } 360 \text { days } \\
(95 \% \mathrm{CI})\end{array}$ \\
\hline 30 & 177 & $58(32.8)$ & $119(67.2)$ & 18.1 (12.9 to 25.0$)$ & 25.7 (19.6 to 33.4$)$ & $36.4(29.1$ to 44.8$)$ \\
\hline 31 & 259 & $69(26.6)$ & $190(73.4)$ & 13.3 (9.6 to 18.4$)$ & $18.8(14.3$ to 24.5$)$ & $30.1(24.2$ to 37.0$)$ \\
\hline 32 & 335 & $72(21.5)$ & $263(78.5)$ & $12.4(9.1$ to 16.8$)$ & $18.0(13.9$ to 23.1$)$ & 25.9 (20.8 to 31.9$)$ \\
\hline 33 & 486 & $95(19.5)$ & $391(80.5)$ & $12.2(9.4$ to 15.7$)$ & 16.1 (12.9 to 20.1$)$ & 22.7 (18.7 to 27.5$)$ \\
\hline Total & 1,257 & $294(23.4)$ & $963(76.6)$ & $13.3(11.5$ to 15.5$)$ & $18.6(16.4$ to 21.1$)$ & 27.3 (24.5 to 30.2$)$ \\
\hline
\end{tabular}

*Using the Kaplan-Meier product limit method.

${ }^{\dagger}$ No. of censored means the number of the infants who did not have readmission following discharge from neonatal intensive care unit. 


\section{3. 전체 재입원}

대상 환아 1,257 명 중 294명(23.4\%)이 NICU 퇴원 후 조사 시 점까지 재입원이 필요했던 것으로 조사되었으며 재태주령 별로 는 각각 30주는 58명(32.8\%), 31주는 69명(26.6\%), 32주는 72명 (21.5\%), 33주는 95명 (19.5\%)이었다.

NICU 퇴원 후 360 일까지 누적 재입원율은 $27.3 \%$ 이었으며 이 를 다시 재태주령 별로 살펴보면 각각 30 주는 $36.4 \%, 31$ 주는 $30.1 \%, 32$ 주는 $25.9 \%, 33$ 주는 $22.7 \%$ 이었다. 대상 환아들의 $\mathrm{NICU}$ 퇴원 후 90 일까지의 누적 재입원율은 $13.3 \%, 180$ 일까지의 누적 재입원율은 $18.6 \%$ 였다. 재태주령 별 90일, 180 일까지의 누적 재 입원율은 Table 3 과 같았다.

\section{4. 호흡기 관련 재입원}

대상 환아 1,257 명 중 176 명 $(14.0 \%)$ 이 NICU 퇴원 후 조사 시점 까지 호흡기 관련 재입원이 필요했던 것으로 조사되었으며 재태 주령 별로는 각각 30주는 38명 (21.5\%), 31주는 36명(13.9\%), 32 주는 41명(12.2\%), 33주는 61명(12.6\%)이었다. 전체 재입원에서 호흡기 관련 재입원이 차지하는 비율은 $59.8 \%$ (176/294) 이었으 며 재태주령 별로 살펴보면 각각 30주는 $65.5 \%$ (38/58), 31주는 $52.2 \%$ (26/69), 32주는 56.9\% (41/72), 33주는 64.2\% (61/95)를 보였다.

NICU 퇴원 후 360 일까지 호흡기 관련 누적 재입원율은 $16.3 \%$ 이었으며 이를 다시 재태주령 별로 살펴보면 각각 30 주는 $23.6 \%$, 31 주는 $15.1 \%, 32$ 주는 $16.0 \%, 33$ 주는 $14.1 \%$ 이었다. 대상 환아들 의 NICU 퇴원 후 90 일까지의 호흡기 관련 누적 재입원율은 $6.1 \%$, 180 일까지의 호흡기 관련 누적 재입원율은 $10.8 \%$ 이었다. 재태주 령 별 90일, 180 일까지의 호흡기 관련 누적 재입원율은 Table 4와 같았다.

\section{RSV 관련 재입원}

호흡기 관련 재입원의 52.8\% (93/176) 에서 호흡기관련바이 러스검사를 시행했으며 이 중 RSV 감염으로 진단된 환아는 $57 \%$ (53/93)이었다. RSV 감염으로 진단된 환아의 비율을 재태주령 별 로 살펴보면 각각 30 주는 $61.1 \%, 31$ 주는 $50.0 \%, 32$ 주는 $45.0 \%$, 33 주는 $67.7 \%$ 이었다.

\section{6. 재태주령 별 전체 재입원율 및 호흡기 관련 재입원율 비교}

전체 재입원율은 재태주령이 증가할수록 통계적으로 유의한 감소 추세를 보였으나(Log-rank test for trend, $P$-value $=0.0034$ ) 호흡기 관련 재입원율은 재태주수 별 추세에서 통계적으로 유 의한 차이는 없었다(Log rank test for trend, $P$-value $=0.0558$ ) (Figure 2). Pair-wise 비교를 통한 전체 재입원율에 대한 재태 주령 별 비교에서 재태주령 30 주 환아들의 전체 재입원율이 재 태주령 33주 환아들에 비해 통계적으로 유의하게 높았으나(30 weeks gestational age (GA) vs. 33 weeks GA: corrected $P$-value $=0.0276$ ), 재태주령 31주, 32주 환아들과의 차이는 없었다(30 weeks GA vs. 31 weeks GA: corrected $P$-value $=1.000$, 30 weeks GA vs. 32 weeks GA: corrected $P$-value $=0.1668$ ). 재태주령 31 주에서 33주 환아들의 NICU 퇴원 후 전체 재입원율 pair-wise 비 교에서는 각 군간의 통계적으로 유의한 차이는 없었다(31 weeks GA vs. 32 weeks GA: corrected $P$-value $=1.000,31$ weeks GA vs 33 weeks GA: corrected $P$-value $=0.6372,32$ weeks GA vs. 33 weeks GA: corrected $P$-value $=1.000$ ).

호흡기 관련 재입원율에 대한 재태주령 별 pair-wise 비교에 서 재태주령 30주 환아와 재태주령 31-33주 환아들의 호흡기 관 련 재입원율은 통계적으로 유의한 차이가 없었다(30 weeks GA vs. 31 weeks GA: corrected $P$-value $=0.2826,30$ weeks GA vs

Table 4. Respiratory Readmission Rate of the Enrolled Infants Following Discharge from the Neonatal Intensive Care Unit

\begin{tabular}{|c|c|c|c|c|c|c|c|}
\hline \multirow{2}{*}{$\begin{array}{l}\text { Gestational age, } \\
\text { week }\end{array}$} & \multirow[b]{2}{*}{ No. of total } & \multirow{2}{*}{$\begin{array}{l}\text { No. of } \\
\text { lst readmission } \\
(\%)\end{array}$} & \multirow{2}{*}{$\begin{array}{c}\text { RSV related } \\
\text { readmission } \\
(\%)\end{array}$} & \multirow{2}{*}{$\begin{array}{c}\text { No. of } \\
\text { censored }^{*} \\
(\%)\end{array}$} & \multicolumn{3}{|c|}{ Readmission rate* } \\
\hline & & & & & $\begin{array}{l}\text { at } 90 \text { days } \\
(95 \% \mathrm{CI})\end{array}$ & $\begin{array}{l}\text { at } 180 \text { days } \\
(95 \% \mathrm{CI})\end{array}$ & $\begin{array}{l}\text { at } 360 \text { days } \\
(95 \% \mathrm{CI})\end{array}$ \\
\hline 31 & 259 & $36(13.9)$ & $12(50.0)$ & $223(86.1)$ & $4.2(2.3$ to 7.6$)$ & $9.6(6.4$ to 14.4$)$ & 15.1 (10.9 to 20.9) \\
\hline 32 & 335 & $41(12.2)$ & $9(45.0)$ & $294(87.8)$ & $6.0(3.8$ to 9.4$)$ & 10.8 (7.6 to 15.2$)$ & $16.0(11.9$ to 21.4$)$ \\
\hline
\end{tabular}

*Using the Kaplan-Meier product limit method.

${ }^{\dagger}$ Respiratory syncytial virus (RSV) related respiratory readmission is defined to be confirmed with laboratory test about RSV and percentage means the portion of RSV related readmission out of the respiratory readmission at which laboratory tests for respiratory related viruses were performed.

${ }^{\ddagger}$ No. of censored means the number of the infants who did not have readmission following discharge from neonatal intensive care unit. 

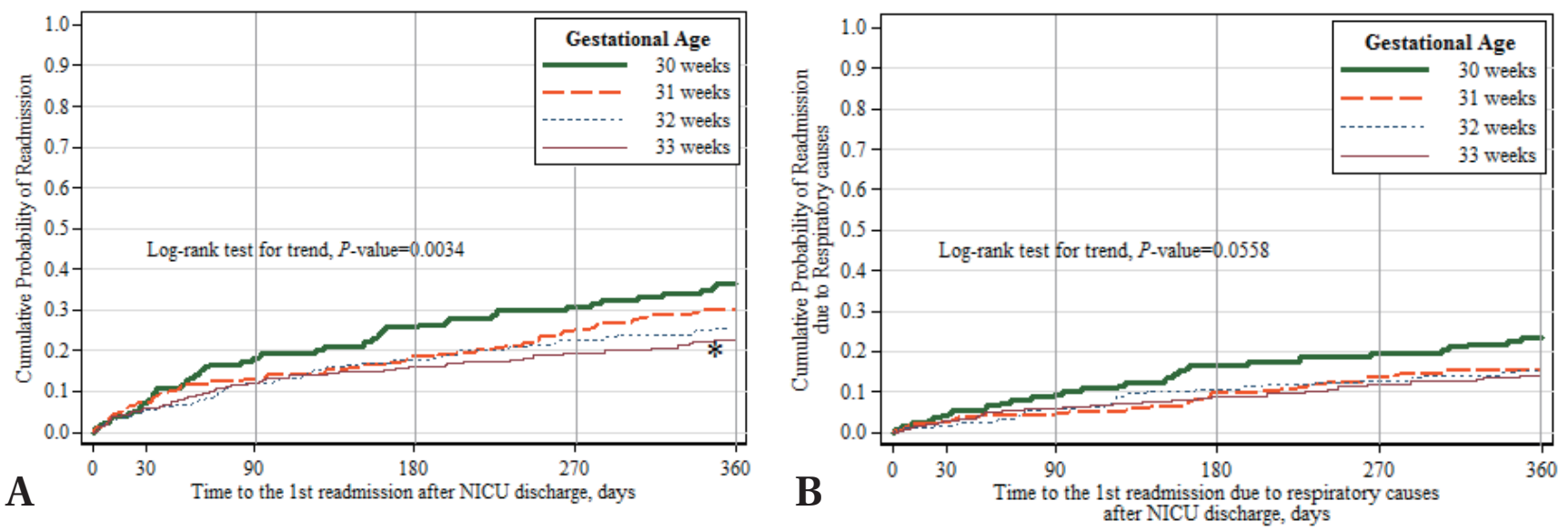

Figure 2. Time in days to the first readmission following discharge from the neonatal intensive care unit (NICU). Kaplan-Meier curves are shown for overall readmission (A) and respiratory readmission (B) during the 360 days following discharge from the NICU in preterm infants of 30-33 weeks gestational age(GA). A log-rank test was used to evaluate the changing trend of readmission rate according to GA group and showed decreasing trend in readmission rate as GA increases. However, significant difference is only observed between GA 30 weeks and GA 33 weeks in overall readmission by Pair-wise comparison $\left({ }^{*} P<0.05\right)$.

32 weeks GA: corrected $P$-value $=0.1524,30$ weeks GA vs. 33 weeks GA: corrected $P$-value $=0.1548$ ). 재태주령 31주에서 33주 환아들의 비교에서도 각 군간의 통계적으로 유의한 차이는 없었 다(31 weeks GA vs. 32 weeks GA: corrected $P$-value=1.000, 31 weeks GA vs. 33 weeks GA: corrected $P$-value $=1.000,32$ weeks GA vs. 33 weeks GA: corrected $P$-value $=1.000$ ).

\section{고찰}

전국적인 대규모 조사로 시행된 본 연구 결과 국내 극소미숙아 의 상한에 있는 재태주령 30 주, 31 주와 중도미숙아인 재태주령 32 주, 33 주의 미숙아들은 NICU 퇴원 후 1년까지 $27.3 \%$ 에서 재입 원하였고 이들의 반이 넘는 전체의 $16.3 \%$ 가 호흡기 원인으로 재 입원함을 알 수 있었다. 이 중에서도 극소미숙아의 최상한인 재태 주령 31 주군과 중도미숙아의 하한인 재태주령 32 주군의 1년 누 적 재입원율은 각각 $30.1 \%$ 와 $25.9 \%$, 호흡기 관련 누적 재입원율 은 각각 $15.1 \%, 16.0 \%$ 로 통계적 차이가 전혀 없이 동일한 의료 이 용 행태를 보이는 의료적 취약군임을 알 수 있었다.

특히 본 연구의 대상은 국내 전국 46개 병원에서 6 개월간에 태 어난 재태주령 30-33주 환아 1,289명이었다. 이는 Chang $^{28)}$ 의 보 고에 따르면 이 연령대의 국내 출생아가 연간 약 3,500 명 정도이 므로, 6 개월의 국내 총 출생아가 1,750 명 정도로 예상되는 바 이 의 약 $75 \%$ 에 해당되는 많은 수로써 역학적인 면에서 국내의 인구 학적 대표성을 확보하기에 그 의의가 매우 크다 하겠다.

세계보건기구(World Health Organization)의 정의에 따른 재태 주령 28-31주에 출생한 극소미숙아와 32-33주에 출생한 중도미
숙아들은 높은 사망률과 이환율을 보이는 것으로 알려져 있다 ${ }^{29-}$ ${ }^{32)}$. 따라서 극소미숙아와 중도미숙아들의 NICU 퇴원 후 의료 이 용 행태에 대한 연구는 이들에 대한 적절한 건강 관리 목표뿐 아 니라 조산으로 비롯된 합병증을 감소시키거나 예방할 수 있는 치 료 계획을 설정하는 데에 도움이 될 수 있다. 특히 중도미숙아의 의료 이용 행태에 대한 기존의 연구 결과는 재태주령 28 주 미만의 초극소미숙아(extremely preterm infants)들과 함께 분석되는 과 정에서 상대적으로 간과되었던 한계를 가지고 있다. Kuzniewicz 등 ${ }^{22}$ 은 재태주령 30 주 이하의 미숙아뿐 아니라 중도미숙아 및 후 기미숙아의 재입원 위험도 역시 만삭아에 비해 유의하게 높았다 고 하였다. 또한 재태주령 30-34주의 미숙아는 미국에서 출생하 는 미숙아의 $32 \%$ 와 NICU에 입원하는 신생아의 $27-38 \%$ 를 차지 하는 규모가 큰 대상 환자군이다 ${ }^{32}$.

Underwood 등 ${ }^{33)}$ 은 재태주령 30주, 31주, 32주, 33주 미숙아의 생후 1년 간의 재입원율이 각각 $19 \%, 16 \%, 15 \%, 14 \%$ 였음을 보 고하였다. Escobar 등 ${ }^{22}$ 은 재태주령 30-34주 미숙아들의 NICU 퇴원 후 3 개월 내 재입원율이 $11.3 \%$ 였음을 보고하였다. 본 연구 의 NICU 퇴원 후 90 일 간 재입원율은 $13.3 \%$ 로 Escobar 등의 연구 와 유사한 결과를 보였다. Underwood 등의 연구에서 사용한 재 입원 발생의 관찰 기간은 생후 1 년으로 본 연구의 NICU 퇴원 후 180 일 간 재입원율 $18.6 \%$ 와 360 일 간 재입원율 $27.3 \%$ 를 고려하 여 비교하였을 때 역시 유사한 결과를 보였다.

Rasler 등 ${ }^{34}$ 은 재태주령 32주 미만 미숙아를 대상으로 한 연구 에서 생후 1 년 동안 호흡기 관련 재입원이 전체 재입원의 $42.1 \%$ 를 차지하였다고 보고하였다. Kim 등 ${ }^{35}$ 의 극소저체중출생아를 대 상으로 한 연구에서는 호흡기 관련 재입원이 전체 재입원의 $56 \%$ 를 차지하였다. 본 연구에서 호흡기 관련 재입원이 전체 재입원 
의 $59.8 \%$ 를 차지하였는데 이는 본 연구의 대상을 고려할 때 더 어 리고 작은 미숙아들처럼 재태주령 30-34주에 출생한 미숙아의 NICU 퇴원 후 호흡기 관련 재입원이 이들의 퇴원 후 관리에서 가 장 흔하고 중요한 문제임을 확인할 수 있는 결과라 하겠다.

Paes 등 ${ }^{36)}$ 은 재태주령 32주 이하 미숙아와 33-35주 미숙아의 비교 연구에서 RSV 관련 재입원의 위험도가 두 군간의 차이가 없 었으며 시나지스 접종에 대한 높은 순응도를 보인 미숙아에서 RSV 관련 재입원이 유의하게 감소하였다고 보고하였다. Kim 등 35$)$ 의 연구에서도 호흡기 관련 재입원의 원인에서 RSV 감염이 $32 \%$ 로 높은 비율을 차지하였다. Park 등 ${ }^{37)}$ 은 재태주령 35주 미만의 미 숙아를 대상으로 한 연구에서 RSV 감염은 NICU 퇴원 후 재입원의 주요 원인 중 하나임을 보고하였다. Park 등 ${ }^{38)}$ 은 하기도 감염으로 입원한 24개월 미만 영유아의 RSV 검출률 비교 연구에서 만삭 출 생아에 비해 미숙아로 출생했던 영유아의 RSV 검출률이 유의하 게 높았으나 재태주령 28주 미만, 28-32주, 32-35주, 35-37주로 나눈 재태주령 별 비교에서는 유의한 차이가 없었다고 하였다. 본 연구에서도 입원 당시 호흡기관련바이러스 검사를 시행한 호흡 기 관련 재입원에 대한 RSV 관련 재입원율은 각각 30주(61.1\%), 31 주(50.0\%), 32주(45.0\%), 33주(67.7\%)로 유의한 차이는 없었 다. 외국의 경우 재태주령 35 주 이하에 출생한 6 개월 미만 영아에 대한 시나지스 예방요법의 유효성과 안전성을 입증한 보고를 근 거로 이들에 대한 시나지스 예방요법을 시행하고 있다. 현재 우리 나라에서는 시나지스 예방요법의 대상이 재태주령 31주 이하에 출생한 6 개월 미만의 미숙아로 한정되고 있다. 그러나 본 연구 결 과를 볼 때 재태주령 32 주, 33 주 미숙아인 경우에 전체 재입원율, 호흡기 재입원율, RSV 유병율에 있어서 재태주령 31주 미숙아와 통계적 차이 없이 동일한 취약성을 보이는 바 이들에게도 시나지 스 예방요법의 확대 실시가 필요할 것으로 생각된다.

본 연구를 통해 재태주령 별 재입원율 비교 분석에서 재태주령 33 주 미숙아의 전체 재입원율이 재태주령 30 주 미숙아보다 유의 하게 낮았던 것 외에 전체 재입원 및 호흡기 관련 재입원율에 있 어 재태주령 별 유의한 차이는 없었다. 특히 극소미숙아에 속하는 재태주령 30 주, 31 주 미숙아 및 32주, 33주에 출생한 중도미숙아 의 NICU 퇴원 후 재입원 및 RSV 관련 재입원 등이 유사한 집단을 대상으로 한 국외 보고와 동일한 양상을 보임을 확인하였다. 따라 서 기존 연구들의 주요 대상인 초극소미숙아 뿐 아니라 재태주령 30-33주에 출생한 미숙아 역시 NICU 퇴원 후 호흡기 관련 재입 원 등 의료 서비스 이용의 위험군임을 확인할 수 있는 결과라 하 겠다.

본 연구는 의무기록 조사를 통한 후향적 연구이며 환자 별 추적 관찰 기간이 상이하였다는 제한점이 있다. 하지만 조사 대상 변수 의 정의를 명확히 제시하였을 뿐 아니라 확인과 감사를 통해 데이 터의 정확성을 검증함으로써 후향적 연구의 한계를 보완하였다.
아울러 가장 늦게 출생한 대상 환아의 최소 추적 관찰 기간을 1 년 이상으로 확보하고 환자 간 추적 기간의 차이를 좁히기 위해 조사 대상 의무기록의 최종 작성일을 확정하여 연구를 진행하였다.

결론적으로 재태주령 30-33주 미숙아의 27.3\%에 해당하는 환 아들이 NICU 퇴원 후 1 년 간 재입원을 하였다. 호흡기 관련 재입 원은 NICU 퇴원 후 약 1 년 동안 재입원의 가장 흔한 원인이었으 며 RSV는 호흡기 관련 재입원의 가장 흔한 원인 바이러스였다. 또 한 재태주령 별 분석에서 각 재태주령 별 호흡기 관련 재입원율의 유의한 차이는 없었다. 이 연구는 재태주령 30-33주에 출생한 극 소미숙아와 중도미숙아의 재입원에 관한 국내외 연구가 부족한 상황에서 각 재태주령 별 재입원율을 조사했다는 점에서 의미가 있다. 따라서 NICU 퇴원 후 호흡기 재입원을 비롯한 의료 서비스 이용 및 장기적 합병증 이환에 있어서 이미 고위험군으로 알려져 있는 초극소미숙아뿐 아니라 재태주령 30-31주의 극소미숙아 및 재태주령 32-33주의 중도미숙아에 대해 적절한 퇴원 후 관리 및 지원이 필요할 것으로 생각된다.

\section{감사의 글}

본 연구는 대한신생아학회 조사통계위원회 RHANPI II 연구비 (PHO1125915)로 시행되었습니다.

전자증례기록서 개발과 관리, 정보처리에 도움을 준 삼성서울 병원 임상의학연구소 $\mathrm{A}-\mathrm{CRO}$ 팀 김수희, 권예경, 복혜숙님께 감사 드리며, 통계분석을 담당한 윤혜경, 김선우 박사님께도 감사를 드 립니다. 아울러 본 연구에 적극적으로 참여해 주신 각 병원의 책 임연구자를 비롯한 여러 선생님들께 깊은 감사의 말씀을 드립니 다. 참여 병원과 각 병원의 책임연구자 선생님들의 명단은 다음과 같습니다:

가톨릭대학교 서울성모병원 성인경, 가톨릭대학교 성모병원 김소영, 강릉아산병원 진현승, 건국대학교병원 김민희, 건양대학 교병원 임재우, 경북대학교병원 김행미, 경상대학교병원 박찬후, 경희대학교 의과대학 강동경희대병원 배종우, 계명대학교 동산 병원 김천수, 고려대학교 의과대학 부속 구로병원 홍영숙, 고려대 학교 의과대학 부속 안산병원 최병민, 단국대 의과대학 부속병원 장영표, 대구파티마병원 김원덕, 동국대학교 일산불교병원 김희 섭, 동아대학교병원 김묘징, 부산대학교병원 박경희, 분당서울대 학교병원 최창원, 삼성서울병원(주관연구기관) 장윤실, 삼성의료 재단 창원삼성병원 최서희, 서울대학교병원 김한석, 서울아산병 원 김애란, 성광의료재단차병원 김은선, 아주대학교병원 이장훈, 양산부산대학교병원 변신연, 연세대학교 원주의과대학 원주기독 병원 임백근, 연세대학교 의과대학 강남세브란스병원 이순민, 연 세대학교 의과대학 세브란스병원 남궁란, 원광대학교병원 오연 
균, 의료법인 길의료재단 길병원 손동우, 이화여대 부속 목동병원 박은애, 인제대학교 부속 부산백병원 전가원, 인제대학교 부속 상 계백병원 심규홍, 인제대학교 부속 일산백병원 황종희, 전남대학 교병원 송은송, 전북대학교병원 조수철, 제일의료 재단 제일병원 신손문, 제주대학교병원 김영돈, 조선대학교병원 박상기, 좋은문 화병원 서손상, 차의과대학교 분당차병원 조희승, 충남대학교병 원 장미영, 학교법인 동은학원 순천향대학교 부속 서울병원 이우 령, 학교법인 노원을지병원 윤혜선, 학교법인 을지대학병원 김승 연, 한림대 부속 강남성심병원 성태정, 한양대학교 의과대학 부속 구리병원 김창렬(가나다순)

\section{REFERENCES}

1) Chien YH, Tsao PN, Chou HC, Tang JR, Tsou KI. Rehospitalization of extremely-low-birth-weight infants in first 2 years of life. Early Hum Dev 2002;66:33-40.

2) McCormick MC, Shapiro S, Starfield BH. Rehospitalization in the first year of life for high-risk survivors. Pediatrics 1980;66: 991-9

3) Morris BH, Gard CC, Kennedy K, Network NNR. Rehospitalization of extremely low birth weight (ELBW) infants: are there racial/ethnic disparities? J Perinatol 2005;25:656-63.

4) Lamarche-Vadel A, Blondel B, Truffer P, Burguet A, Cambonie $\mathrm{G}$, Selton D, et al. Re-hospitalization in infants younger than 29 weeks' gestation in the EPIPAGE cohort. Acta Paediatr 2004;93:1340-5.

5) Hack M, DeMonterice D, Merkatz IR, Jones P, Fanaroff AA. Rehospitalization of the very-low-birth-weight infant. A continuum of perinatal and environmental morbidity. Am J Dis Child 1981;135:263-6.

6) Elder DE, Hagan R, Evans SF, Benninger HR, French NP. Hospital admissions in the first year of life in very preterm infants. J Paediatr Child Health 1999;35:145-50.

7) Heilman CA. From the National Institute of Allergy and Infectious Diseases and the World Health Organization. Respiratory syncytial and parainfluenza viruses. J Infect Dis 1990;161:402-6.

8) Groothuis JR, Simoes EA, Hemming VG. Respiratory syncytial virus (RSV) infection in preterm infants and the protective effects of RSV immune globulin (RSVIG). Respiratory Syncytial Virus Immune Globulin Study Group. Pediatrics 1995;95:463-7.

9) Reduction of respiratory syncytial virus hospitalization among premature infants and infants with bronchopulmonary dysplasia using respiratory syncytial virus immune globulin prophylaxis. The PREVENT Study Group. Pediatrics
1997;99:93-9.

10) Palivizumab, a humanized respiratory syncytial virus monoclonal antibody, reduces hospitalization from respiratory syncytial virus infection in high-risk infants. The IMpact-RSV Study Group. Pediatrics 1998;102:531-7.

11) Joffe S, Escobar GJ, Black SB, Armstrong MA, Lieu TA. Rehospitalization for respiratory syncytial virus among premature infants. Pediatrics 1999;104:894-9.

12) Wang EE, Law BJ, Stephens D. Pediatric Investigators Collaborative Network on Infections in Canada (PICNIC) prospective study of risk factors and outcomes in patients hospitalized with respiratory syncytial viral lower respiratory tract infection. J Pediatr 1995;126:212-9.

13) Reiff MI. Adolescent school failure: failure to thrive in adolescence. Pediatr Rev 1998;19:199-207.

14) Bont L, van Vught AJ, Kimpen JL. Prophylaxis against respiratory syncytial virus in premature infants. Lancet 1999;354: 1003-4.

15) Roeckl-Wiedmann I, Liese JG, Grill E, Fischer B, Carr D, Belohradsky BH. Economic evaluation of possible prevention of RSV-related hospitalizations in premature infants in Germany. Eur J Pediatr 2003;162:237-44.

16) Carbonell Estrany $X$, Quero Jimenez J. Recommendations for the prevention of respiratory syncytial virus infections. Standards Committee of the Spanish Society of Neonatology. Board of Directors of the Spanish Society of Neonatology. An Esp Pediatr 2000;52:372-4.

17) Feltes TF, Cabalka AK, Meissner HC, Piazza FM, Carlin DA, Top FH, Jr., et al. Palivizumab prophylaxis reduces hospitalization due to respiratory syncytial virus in young children with hemodynamically significant congenital heart disease. J Pediatr 2003;143:532-40.

18) Simoes EA, Groothuis JR. Respiratory syncytial virus prophylaxis--the story so far. Respir Med 2002;96:S15-24.

19) Simoes EA. Immunoprophylaxis of respiratory syncytial virus: global experience. Respir Res 2002;3:S26-33.

20) Korvenranta E, Lehtonen L, Peltola M, Hakkinen U, Andersson S, Gissler M, et al. Morbidities and hospital resource use during the first 3 years of life among very preterm infants. Pediatrics 2009;124:128-34.

21) Landry JS, Croitoru D, Jin Y, Schwartzman K, Benedetti A, Menzies D. Health care utilization by preterm infants with respiratory complications in Quebec. Can Respir J 2012;19: 255-60.

22) Kuzniewicz MW, Parker SJ, Schnake-Mahl A, Escobar GJ. Hospital readmissions and emergency department visits in Canadian respiratory journal : journal of the Canadian Thoracic Society moderate preterm, late preterm, and early term infants. Clin Perinatol 2013;40:753-75. 
23) Mourani PM, Kinsella JP, Clermont G, Kong L, Perkins AM, Weissfeld $\mathrm{L}$, et al. Intensive care unit readmission during childhood after preterm birth with respiratory failure. J Pediatr 2014;164:749-55 e3.

24) Shennan AT, Dunn MS, Ohlsson A, Lennox K, Hoskins EM. Abnormal pulmonary outcomes in premature infants: prediction from oxygen requirement in the neonatal period. Pediatrics 1988;82:527-32.

25) Walsh MC, Kliegman RM. Necrotizing enterocolitis: treatment based on staging criteria. Pediatr Clin North Am 1986;33 :179-201.

26) Papile LA, Burstein J, Burstein R, Koffler H. Incidence and evolution of subependymal and intraventricular hemorrhage: a study of infants with birth weights less than 1,500 gm. J Pediatr 1978;92:529-34.

27) Garner JS, Jarvis WR, Emori TG, Horan TC, Hughes JM. CDC definitions for nosocomial infections, 1988. Am J Infect Control 1988;16:128-40.

28) Chang YS; The Committee on Data Collection and Statistics of the Korean Society of Neonatology. The survey on the actual conditions of neonatal intensive care units and analysis of survival rate of high-risk newborn infants. 2010 Report of Management Center for Health Promotion 2010. Seoul: The Korean Society of Neonatology.

29) Kramer MS, Demissie K, Yang H, Platt RW, Sauve R, Liston R. The contribution of mild and moderate preterm birth to infant mortality. Fetal and Infant Health Study Group of the Canadian Perinatal Surveillance System. JAMA 2000;284:8439.

30) Yoder BA, Gordon MC, Barth WH, Jr. Late-preterm birth: does the changing obstetric paradigm alter the epidemiology of respiratory complications? Obstet Gynecol 2008;111:814-22.
31) Wang ML, Dorer DJ, Fleming MP, Catlin EA. Clinical outcomes of near-term infants. Pediatrics 2004;114:372-6.

32) Escobar GJ, McCormick MC, Zupancic JA, Coleman-Phox K, Armstrong MA, Greene JD, et al. Unstudied infants: outcomes of moderately premature infants in the neonatal intensive care unit. Arch Dis Child Fetal Neonatal Ed 2006;91:F238-44.

33) Underwood MA, Danielsen B, Gilbert WM. Cost, causes and rates of rehospitalization of preterm infants. J Perinatol 2007; 27:614-9.

34) Ralser E, Mueller W, Haberland C, Fink FM, Gutenberger KH, Strobl R, et al. Rehospitalization in the first 2 years of life in children born preterm. Acta Paediatr 2012;101:e1-5.

35) Kim SJ, Chae SH, Lee JH, Kim YJ, Koo SH, Jeon GW, et al. Rehospitalization of very low birth weight infants in the first year after discharge from NICU and risk factor of rehospitalization caused by respiratory illness. J Korean Soc Neonatol 2006;13:17-23.

36) Paes B, Mitchell I, Li A, Lanctot KL, Investigators C. A comparative study of respiratory syncytial virus (RSV) prophylaxis in premature infants within the Canadian Registry of Palivizumab (CARESS). Eur J Clin Microbiol Infect Dis 2012; 31:2703-11.

37) Park HW, Lee BS, Kim AR, Yoon HS, Kim BI, Song ES, et al. Epidemiology of respiratory syncytial virus infection in infants born at less than thirty-five weeks of gestational age. Pediatr Infect Dis J 2012;31:e99-104.

38) Park KH, Shin JH, Lee EH, Seo WH, Kim YK, Song DJ, et al. Seasonal variations of respiratory syncytial virus infection among the children under 60 months of age with lower respiratory tract infections in the capital area, the Republic of Korea, 2008-2011. J Korean Soc Neonatol 2012;19:195-203. 